\title{
Chromium concentrations in ruminant feed ingredients
}

\author{
J. W. Spears, ${ }^{* 1}$ K. E. Lloyd, ${ }^{*}$ and K. Krafka† \\ *Department of Animal Science, North Carolina State University, Raleigh 27695-7621 \\ †Kemin Industries Inc., Des Moines, IA 50317
}

\begin{abstract}
Chromium $(\mathrm{Cr})$, in the form of $\mathrm{Cr}$ propionate, has been permitted for supplementation to cattle diets in the United States at levels up to $0.50 \mathrm{mg}$ of $\mathrm{Cr} / \mathrm{kg}$ of DM since 2009. Little is known regarding $\mathrm{Cr}$ concentrations naturally present in practical feed ingredients. The present study was conducted to determine $\mathrm{Cr}$ concentrations in feed ingredients commonly fed to ruminants. Feed ingredients were collected from dairy farms, feed mills, grain bins, and university research farms. Mean $\mathrm{Cr}$ concentrations in whole cereal grains ranged from $0.025 \mathrm{mg} / \mathrm{kg}$ of DM for oats to $0.041 \mathrm{mg} /$ $\mathrm{kg}$ of DM for wheat. Grinding whole samples of corn, soybeans, and wheat through a stainless steel Wiley mill screen greatly increased analyzed Cr concentrations. Harvested forages had greater $\mathrm{Cr}$ concentrations than concentrates, and alfalfa hay or haylage had greater $\mathrm{Cr}$ concentrations than grass hay or corn silage. Chromium in alfalfa hay or haylage $(\mathrm{n}=13)$ averaged $0.522 \mathrm{mg} / \mathrm{kg}$ of DM, with a range of 0.199 to $0.889 \mathrm{mg} /$ $\mathrm{kg}$ of DM. Corn silage $(\mathrm{n}=21)$ averaged $0.220 \mathrm{mg}$ of $\mathrm{Cr} / \mathrm{kg}$ of DM with a range of 0.105 to $0.441 \mathrm{mg}$ of $\mathrm{Cr} /$ $\mathrm{kg}$ of DM. By-product feeds ranged from $0.040 \mathrm{mg}$ of $\mathrm{Cr} / \mathrm{kg}$ of DM for cottonseed hulls to $1.222 \mathrm{mg}$ of $\mathrm{Cr} /$ $\mathrm{kg}$ of DM for beet pulp. Of the feed ingredients analyzed, feed grade phosphate sources had the greatest $\mathrm{Cr}$ concentration $(135.0 \mathrm{mg} / \mathrm{kg})$. Most ruminant feedstuffs and feed ingredients had less than $0.50 \mathrm{mg}$ of $\mathrm{Cr} / \mathrm{kg}$ of DM. Much of the analyzed total $\mathrm{Cr}$ in feed ingredients appears to be due to $\mathrm{Cr}$ contamination from soil or metal contact during harvesting, processing, or both.
\end{abstract}

Key words: chromium, cattle, feed ingredients, ruminants

\section{INTRODUCTION}

Chromium $(\mathrm{Cr})$ potentiates the action of insulin in insulin-sensitive tissues, and based on research in hu-

Received October 14, 2016.

Accepted December 30, 2016.

${ }^{1}$ Corresponding author: Jerry_Spears@ncsu.edu mans, the Institute of Medicine established an adequate intake of Cr for humans (National Academies, 2001). Chromium concentrations in foods and diets consumed by humans have also been reported (Anderson et al., 1992).

Before the early 1990s, practical diets fed to cattle were generally assumed to provide adequate $\mathrm{Cr}$ to meet dietary requirements. However, studies conducted in the early 1990s indicated that $\mathrm{Cr}$ supplementation could improve performance and reduce morbidity in stressed calves (Moonsie-Shageer and Mowat, 1993; Mowat et al., 1993). Subsequent research demonstrated that $\mathrm{Cr}$ supplementation during late gestation and early lactation increased milk production in dairy cows (Yang et al., 1996; Hayirli et al., 2001).

The US Food and Drug Administration Center for Veterinary Medicine issued a regulatory discretion letter in 2009, which permitted the use of $\mathrm{Cr}$ propionate (Cr Prop) as a source of Cr for supplementation to cattle diets at levels up to $0.5 \mathrm{mg}$ of $\mathrm{Cr} / \mathrm{kg}$ of $\mathrm{DM}$. Chromium supplementation from Cr Prop was found to enhance insulin sensitivity in growing cattle (Spears et al., 2012). Recent studies have indicated that Cr Prop supplementation may enhance performance and health of stressed calves (Bernhard et al., 2012) and increase milk production in dairy cows (Vargas-Rodriguez et al., 2014; Rockwell and Allen, 2016).

Little is known regarding $\mathrm{Cr}$ concentrations naturally present in practical feedstuffs. Chromium analysis of feed ingredients and total diets is challenging because of the low concentration of $\mathrm{Cr}$ normally present and problems with $\mathrm{Cr}$ contamination of samples during collection, processing, and laboratory preparation of samples for analysis (NRC, 2005). Mean Cr concentrations in homegrown feedstuffs in Wisconsin ranged from 0.33 $\mathrm{mg} / \mathrm{kg}$ of DM for corn grain to $0.91 \mathrm{mg} / \mathrm{kg}$ of DM for alfalfa haylage ( $\mathrm{Li}$ et al., 2005). Average $\mathrm{Cr}$ concentrations in unground wheat samples from different areas in Australia ranged from 0.013 to $0.041 \mathrm{mg} / \mathrm{kg}$, and $\mathrm{Cr}$ concentrations in oats and barley were 0.020 and $0.024 \mathrm{mg} / \mathrm{kg}$, respectively (Jones and Buckley, 1977). The objectives of the present study were to determine Cr concentrations in feed ingredients commonly fed to ruminants and to determine the extent of variation that 
Table 1. Summary of feed ingredients analyzed

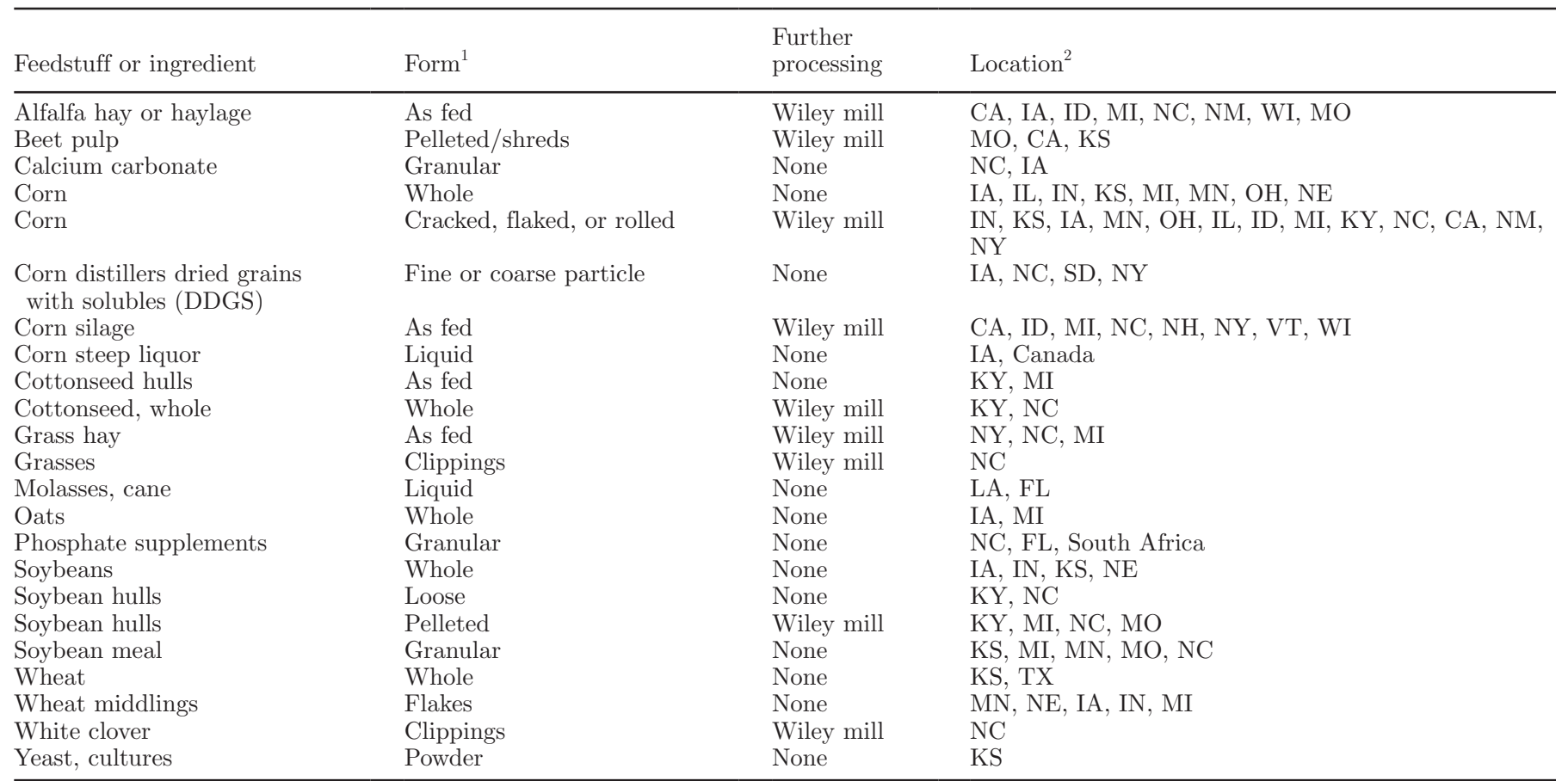

${ }^{1}$ Form in which feed was received.

${ }^{2}$ Location (state or country) from where feedstuff or ingredient was received. $\mathrm{CA}=$ California, $\mathrm{IA}=\mathrm{Iowa}, \mathrm{ID}=\mathrm{Idaho}, \mathrm{MI}=\mathrm{Michigan}, \mathrm{NC}=$ North Carolina, $\mathrm{NM}=$ New Mexico, $\mathrm{WI}=$ Wisconsin, $\mathrm{MO}=$ Missouri, $\mathrm{KS}=$ Kansas, $\mathrm{IL}=\mathrm{Illinois}, \mathrm{IN}=\mathrm{Indiana}, \mathrm{MN}=\mathrm{Minnesota}, \mathrm{OH}=$ Ohio, $\mathrm{NE}=$ Nebraska, $\mathrm{KY}=$ Kentucky, NY $=$ New York, $\mathrm{SD}=$ South Dakota, $\mathrm{NH}=$ New Hampshire, VT $=$ Vermont, LA $=$ Louisiana, FL $=$ Florida, $\mathrm{TX}=$ Texas.

exists within several feed ingredients derived from different geographic areas throughout the United States.

\section{MATERIALS AND METHODS}

Feed ingredients were collected from dairy farms, feed mills, grain bins, and research farms at North Carolina State University (NCSU) and Michigan State University. The number of samples for the various feed ingredients analyzed ranged from $\mathrm{n}=2$ to $\mathrm{n}=$ 21. A summary of the feed ingredients analyzed along with the form received, whether feed ingredients were ground in the laboratory, and the states where feed ingredients were derived is shown in Table 1. All samples were dried in a forced-air oven at $55^{\circ} \mathrm{C}$, and results are expressed on a DM basis.

\section{Forages}

Samples of silage, hay, and haylage were obtained from dairy farms, NCSU, and Michigan State University. Hand-clipped samples of KY 31 tall fescue, Max $\mathrm{Q}$ tall fescue, orchardgrass, and white clover were collected at 2 vegetative stages (April 14 and May 14) from pastures at NCSU. Forage samples were clipped approximately $5 \mathrm{~cm}$ above the ground. Samples were taken from multiple sites within a single pasture of each forage. Following drying, all forage samples were ground through a 1-mm stainless steel screen (Wiley mill; Arthur H. Thomas, Philadelphia, PA).

\section{Concentrates}

Unprocessed samples of corn, wheat, oats, and soybeans were collected from feed mills or on-farm grain bins and prepared for $\mathrm{Cr}$ analysis without grinding to minimize Cr contamination. Samples of soybean meal and ground corn obtained from feed mills were also analyzed for $\mathrm{Cr}$ without further processing. Cracked and flaked corn samples were ground in a Wiley mill before Cr analysis.

\section{By-Product Feedstuffs and Miscellaneous Feed Ingredients}

By-product feed ingredients were obtained from feed mills or from farms and were not processed further before $\mathrm{Cr}$ analysis, unless they were received in a pelleted form. All liquid feed ingredients were obtained from Quality Liquid Feeds (Dodgeville, WI). Liquid 
feed ingredients were wet ashed for $\mathrm{Cr}$ analysis without drying.

\section{Cr Contamination from Grinding}

To determine the effect of grinding grain samples through a laboratory Wiley mill on analyzed $\mathrm{Cr}$ concentrations, samples of whole corn $(\mathrm{n}=8)$, soybeans ( $\mathrm{n}$ $=7)$, and wheat $(\mathrm{n}=5)$ were prepared for $\mathrm{Cr}$ analysis without further processing. A portion of these same grain samples were then ground through a 1-mm stainless steel screen before preparation for $\mathrm{Cr}$ analysis.

\section{Subsampling}

The amount of each feed ingredient sample collected ranged from $100 \mathrm{~g}$ to $1 \mathrm{~kg}$. All ground samples were initially mixed by rotation in their storage bags. All contents were then poured out onto a piece of brown kraft paper large enough to accommodate the entire sample. The sample was further mixed by turning over the consecutive corners of the brown kraft paper multiple times, which in turn mixed the bottom portion with the top portion of the sample. The ground sample was then divided into 4 equal quadrants. One of the quadrants was then subsampled at a minimum of 5 locations until the ashing/digestion weight was obtained.

Unground samples of grains were dried in the oven and stored in bags in the same fashion as the ground samples. Storage bags were thoroughly mixed by rotation, and the sample particles were removed with plastic tweezers from several locations in the bag until the ashing weight was obtained.

\section{Cr Analysis}

Feed ingredient samples were prepared for Cr analysis by wet ashing with trace mineral grade nitric acid (Trace Metal grade, Fisher Scientific, Raleigh, NC). Briefly, for all samples except mineral supplements (calcium carbonate and phosphate sources), an amount weighing between 0.5 and $1.0 \mathrm{~g}$ was predigested at room temperature for 18 to $24 \mathrm{~h}$ with $10 \mathrm{~mL}$ of nitric acid in a 50-mL polypropylene tube. Predigested samples were ashed further using the CEM Hi-Thru Put Method with a Mars5 Microwave (CEM, Matthews, NC). Once microwaving was complete, all acid-digested samples were brought up to a final volume of $25 \mathrm{~mL}$ with deionized $\mathrm{H}_{2} \mathrm{O}$ to allow minimal dilution for $\mathrm{Cr}$ analysis. No particles were present following wet ashing, indicating that acid hydrolysis was complete even for samples that were not ground. For mineral supplements, approximately $0.2 \mathrm{~g}$ was exposed to nitric acid for 18 to $24 \mathrm{~h}$ at room temperature and then brought up to a final volume with deionized $\mathrm{H}_{2} \mathrm{O}$. Calcium carbonate and phosphate sources were analyzed for $\mathrm{Cr}$ using flame atomic absorption spectrophotometry (model 6701, Shimadzu, Kyoto, Japan) because of the high concentration of $\mathrm{Cr}$ present in these samples. Chromium in all other feed ingredients was measured by electrothermal atomic absorption spectrophotometry (GFA-6500, Shimadzu) as described by Lloyd et al. (2010). The method of standard addition was used to remove matrix effects. Each sample plus the standard was run in duplicate. Bovine muscle obtained from the National Institute of Standards and Technology (Washington, DC) and certified to contain $71 \pm 38 \mathrm{ng}$ of $\mathrm{Cr} / \mathrm{g}$ was ashed and analyzed in the same manner as feed ingredient samples. The reference standard was analyzed to contain $81.5 \pm 1.5$ ng $\mathrm{Cr} / \mathrm{g}$.

\section{Statistical Analysis}

Means, SD, and ranges of $\mathrm{Cr}$ concentrations are presented for each feed ingredient. Whole versus ground samples of grain were analyzed by grain type as a randomized block design by ANOVA using the MIXED procedure of SAS (SAS Institute, 2002). The model included block (sample) and treatment.

\section{RESULTS AND DISCUSSION}

Chromium concentrations in concentrate feeds are presented in Table 2. Mean Cr concentrations in whole cereal grains were low, ranging from $0.025 \mathrm{mg} / \mathrm{kg}$ of DM for oats to $0.041 \mathrm{mg} / \mathrm{kg} \mathrm{DM}$ for wheat. Analyzed $\mathrm{Cr}$ concentrations obtained in the present study for oats and wheat were in line with those reported previously (Welch and Cary, 1975; Jones and Buckley, 1977; Cary and Kubota, 1990). Chromium levels in wheat samples collected from different areas in Australia ranged from 0.009 to $0.090 \mathrm{mg} / \mathrm{kg}$ DM (Jones and Buckley, 1977). Wheat samples from different US states analyzed from 0.003 to $0.038 \mathrm{mg}$ of $\mathrm{Cr} / \mathrm{kg}$ of DM (Welch and Cary, 1975). Samples of oats collected in Australia averaged $0.020 \mathrm{mg}$ of $\mathrm{Cr} / \mathrm{kg}$ of DM (Jones and Buckley, 1977). Chromium concentrations in whole corn samples in our study were lower than those reported for corn grain samples collected from dairy farms in Wisconsin ( $\mathrm{Li}$ et al., 2005). This finding could be due to differences in the amount of $\mathrm{Cr}$ contamination during sampling, preparation of samples for analysis, or both or differences in analytical procedures used to measure Cr. Corn samples from the Wisconsin study were ground through a 1-mm plastic screen before ashing, but samples in the present study were not processed before ashing. 
Table 2. Chromium concentrations $(\mathrm{mg} / \mathrm{kg}$ of DM) in concentrate and forage feed ingredients

\begin{tabular}{lcccc}
\hline Feedstuff & $\begin{array}{c}\text { No. of } \\
\text { samples }\end{array}$ & Mean & SD & Range \\
\hline Concentrate & & & & \\
$\quad$ Corn, whole & 16 & 0.026 & 0.015 & $0.008-0.054$ \\
Corn, processed & 16 & 0.049 & 0.031 & $0.014-0.114$ \\
Cottonseed & 2 & 0.094 & 0.086 & $0.033-0.155$ \\
$\quad$ Oats, whole & 3 & 0.025 & 0.008 & $0.021-0.034$ \\
$\quad$ Soybeans, whole & 7 & 0.069 & 0.035 & $0.034-0.122$ \\
$\quad$ Soybean, meal & 6 & 0.208 & 0.050 & $0.154-0.286$ \\
$\quad$ Wheat, whole & 6 & 0.041 & 0.014 & $0.029-0.062$ \\
Forage & 13 & 0.522 & 0.220 & $0.199-0.889$ \\
$\quad$ Alfalfa hay or haylage & 21 & 0.220 & 0.087 & $0.105-0.441$ \\
$\quad$ Corn silage & 5 & 0.155 & 0.093 & $0.098-0.320$ \\
$\quad$ Grass hay & & & & \\
Clipped forage & 2 & 0.101 & 0.010 & $0.094-0.108$ \\
$\quad$ Orchardgrass & 4 & 0.179 & 0.074 & $0.112-0.248$ \\
$\quad$ Tall fescue & 2 & 0.358 & 0.046 & $0.325-0.390$ \\
$\quad$ White clover & & & & \\
\hline
\end{tabular}

Processed (cracked or flaked) corn samples received and then ground through a stainless steel screen had $\mathrm{Cr}$ concentrations almost twice as high as those in whole corn samples (Table 2). Whole cottonseed and soybeans had slightly greater $\mathrm{Cr}$ concentrations than the cereal grains. Soybean meal samples contained the greatest Cr concentrations of the concentrate feeds evaluated in this study.

Harvested forages contained greater $\mathrm{Cr}$ concentrations than concentrates (Table 2). Alfalfa hay or haylage (0.522 $\mathrm{mg}$ of $\mathrm{Cr} / \mathrm{kg}$ of $\mathrm{DM}$ ) contained greater mean $\mathrm{Cr}$ concentrations than corn silage $(0.222 \mathrm{mg} / \mathrm{kg}$ of DM) or grass hay $(0.155 \mathrm{mg} / \mathrm{kg}$ of DM). Li et al. (2005) also reported greater $\mathrm{Cr}$ concentrations in alfalfa hay and haylage compared with corn silage. The greater $\mathrm{Cr}$ levels in forages than in concentrates is not surprising. Previous research indicated that the grain portion of wheat and oats is much lower in $\mathrm{Cr}$ than the plant leaf and stem (Cary and Kubota, 1990). Chromium concentrations in clipped samples of cool season grasses ranged from 0.094 to $0.248 \mathrm{mg}$ of $\mathrm{Cr} / \mathrm{kg}$ of $\mathrm{DM}$ (Table 2 ). White clover contained greater $\mathrm{Cr}$ concentrations than grasses. Subterranean clover samples collected in Australia also contained greater $(0.76$ vs. $0.44 \mathrm{mg} / \mathrm{kg}$ of DM) Cr concentrations than ryegrass samples (Jones and Buckley, 1977).

Chromium concentrations in by-product and miscellaneous feed ingredients are shown in Table 3. Beet pulp $($ mean $=1.222 \mathrm{mg} / \mathrm{kg}$ of DM) and corn steep liquid $(1.053 \mathrm{mg} / \mathrm{kg}$ of $\mathrm{DM})$ contained the greatest $\mathrm{Cr}$ concentrations of the by-product feed ingredients analyzed. The greater $\mathrm{Cr}$ concentrations in beet pulp may be due to greater soil contamination because beets grow underground. With the exception of beet pulp and corn steep liquid, other by-product feed ingredients averaged less than $0.60 \mathrm{mg}$ of $\mathrm{Cr} / \mathrm{kg}$ of DM. Pelleted samples of soybean hulls had greater Cr concentrations than samples of soybean hulls received in a loose form. The greater $\mathrm{Cr}$ concentration in pelleted samples may be due to $\mathrm{Cr}$ contamination occurring during pelleting

Table 3. Chromium concentrations $(\mathrm{mg} / \mathrm{kg}$ of $\mathrm{DM})$ in by-product and miscellaneous feed ingredients

\begin{tabular}{lcccc}
\hline Feedstuff & $\begin{array}{c}\text { No. of } \\
\text { samples }\end{array}$ & Mean & SD & Range \\
\hline Beet pulp & 3 & 1.222 & 0.386 & $0.776-1.451$ \\
Calcium carbonate & 3 & 6.79 & 1.08 & $5.63-7.78$ \\
Corn steep liquor & 2 & 1.053 & 0.426 & $0.752-1.355$ \\
Cottonseed hulls & 2 & 0.040 & 0.013 & $0.031-0.050$ \\
DDGS ${ }^{1}$ loose & 12 & 0.160 & 0.056 & $0.084-0.238$ \\
Molasses, cane & 2 & 0.557 & 0.049 & $0.522-0.591$ \\
Phosphate sources & 5 & 135.0 & 19.8 & $112.0-163.0$ \\
Soybean hulls, loose & 3 & 0.262 & 0.073 & $0.191-0.336$ \\
Soybean hulls, pelleted & 4 & 0.550 & 0.175 & $0.309-0.705$ \\
Wheat middlings & 9 & 0.084 & 0.031 & $0.044-0.132$ \\
Yeast, cultures & 2 & 0.600 & 0.091 & $0.536-0.664$ \\
\hline
\end{tabular}

${ }^{1} \mathrm{DDGS}=$ distillers dried grains with solubles. 
or during grinding of pelleted samples in the laboratory. Pelleted samples were ground through a stainless steel screen, but loose samples were not. By-product feed ingredients generally contained greater $\mathrm{Cr}$ concentrations than the whole grains analyzed.

Calcium carbonate sources averaged $6.79 \mathrm{mg}$ of $\mathrm{Cr} /$ $\mathrm{kg}$, and phosphate sources averaged $135.0 \mathrm{mg}$ of $\mathrm{Cr} /$ $\mathrm{kg}$ (Table 3). Phosphate sources analyzed included monocalcium phosphate, dicalcium phosphate, and defluorinated phosphate. Chromium would be expected to be present as a contaminant in mineral ingredients, and studies (Sullivan et al., 1994; Lima et al., 1995) have indicated that most feed-grade phosphate sources are high in Cr. Chromium concentrations in 9 samples of mono-dicalcium phosphate produced in the United States averaged $203 \mathrm{mg} / \mathrm{kg}$, with a range of 65 to 538 $\mathrm{mg} / \mathrm{kg}$ (Sullivan et al., 1994).

Most complete diets and feedstuffs are typically ground through a Wiley mill screen before laboratory analysis. Table 4 shows a comparison of analyzed $\mathrm{Cr}$ concentrations in whole samples of corn, soybeans, and wheat versus these same samples following grinding through a stainless steel Wiley mill screen. Analyzed Cr concentrations in all grains were significantly increased by grinding. Grinding increased analyzed $\mathrm{Cr}$ values in corn by $150 \%$, wheat by $113 \%$, and soybeans by $87 \%$.

Accurately measuring naturally occurring $\mathrm{Cr}$ in feed ingredients is difficult because of $\mathrm{Cr}$ contamination that can occur during harvesting, processing, and collection of samples as well as laboratory analysis of Cr. Chromium is ubiquitous in nature, occurring in soils, plants, water, and air. It is naturally present primarily in the trivalent form as ferrochromite $\left(\mathrm{FeCr}_{2} \mathrm{O}_{4}\right)$ ores (Katz and Salem, 1994). A large portion of Cr ores are processed for use in the production of stainless steel and other alloys. Chromium is also used as a component of chrome and in chrome plating, leather tanning, and the manufacturing of pigments and wood preservatives. The present study clearly demonstrates that the grinding of whole grain samples through a stainless steel screen significantly increased analyzed Cr concentrations. During feed harvesting and processing, it should be recognized that numerous opportunities exist for $\mathrm{Cr}$ contamination from metal contact.

Soil contamination can also contribute to the total $\mathrm{Cr}$ concentration in feed ingredients and feeds. Cary and Kubota (1990) estimated soil contamination of plant tissues using titanium as a marker of the degree of soil contamination. They found that soil contamination was an important factor contributing to the total $\mathrm{Cr}$ concentration in most plant tissue samples analyzed. The amount of soil contamination in plant samples from this study was likely less than what occurs during
Table 4. Effect of grinding through a stainless steel Wiley mill screen on chromium concentrations of grains

\begin{tabular}{lcccc}
\hline \multirow{2}{*}{ Grain } & \multirow{2}{*}{$\begin{array}{c}\text { No. of } \\
\text { samples }\end{array}$} & Whole & Ground & \\
\cline { 3 - 4 } & & & \\
\cline { 3 - 4 } -value \\
\hline Corn & 8 & 0.020 & 0.050 & 0.01 \\
Soybeans & 7 & 0.077 & 0.144 & 0.02 \\
Wheat & 5 & 0.045 & 0.096 & 0.03 \\
\hline
\end{tabular}

production scale harvesting of hay and silage. Rafferty et al. (1994) found that soil contamination averaged less than $2 \%$ when hay and grass silage samples were obtained fresh before harvest. However, soil contamination rates as high as $8 \%$ were observed in some samples collected after harvesting.

Analytical determination of $\mathrm{Cr}$ also represents another source of variability and error in accurately reporting $\mathrm{Cr}$ concentrations in feed ingredients because of the low $\mathrm{Cr}$ concentrations present and $\mathrm{Cr}$ contamination from reagents used in preparation of samples for analysis. Many $\mathrm{Cr}$ supplementation studies in the past have not included an analysis of experimental diets for $\mathrm{Cr}$ (Hayirli et al., 2001; Van Bibber-Krueger et al., 2016) or have used flame atomic absorption spectroscopy to measure $\mathrm{Cr}$ in diets (Edenburn et al., 2016; Kneeskern et al., 2016). Chromic oxide has frequently been used as a nondigestible marker for digestibility studies. Flame atomic absorption can detect the high concentrations of $\mathrm{Cr}$ found in feed and fecal samples from animals given chromic oxide as a nondigestible marker. However, flame atomic absorption spectrometry is not sensitive enough to detect the low concentrations of $\mathrm{Cr}$ found in most feedstuffs (NRC, 2005). In the present study we attempted to minimize $\mathrm{Cr}$ contamination of samples. We could not control Cr contamination that occurred during harvesting of forages or grains, processing of feed ingredients, or grinding of certain feed ingredients through a stainless steel screen in the laboratory. However, the graphite furnace atomic absorption procedure used in the present study is highly sensitive for measuring low concentrations of $\mathrm{Cr}$ and has a detection limit of $0.005 \mu \mathrm{g}$ of $\mathrm{Cr} / \mathrm{L}$ when an appropriate background correction method is used (NRC, 2005). Nitric acid of the highest purity was used in preparing samples for analysis to avoid $\mathrm{Cr}$ contamination. A sample from the National Institute of Standards and Technology with a certified $\mathrm{Cr}$ concentration was also used as a reference standard. Furthermore, our $\mathrm{Cr}$ analytical procedure has been validated according to CLSI guidelines for a variety of matrices and was reviewed and accepted by the FDA as part of a food additive petition (21CFR573.304). 
Consistent with previous research with human plant foods (Welch and Cary, 1975; Cary and Kubota, 1990), the present study clearly indicates that $\mathrm{Cr}$ uptake by most plants consumed by cattle is low. Chromium is found in soils primarily in insoluble forms (Zayed and Terry, 2003). Soluble forms of Cr added to soil are rapidly converted to insoluble forms (Cary et al., 1977a). Chromium taken up from soils by plants is also poorly translocated from the root to other parts of the plant (Cary et al., 1977b; Lahouti and Peterson, 1979). However, plants appear to vary with regard to Cr translocation from their roots (Cary et al., 1977a; Johnson and Weaver, 1986). For example, kale accumulated more Cr than the edible tissues of wheat and legumes (bush beans and soybeans; Johnson and Weaver, 1986). The present study suggests that legumes are higher in $\mathrm{Cr}$ than grasses. Alfalfa hay and haylage contained greater $\mathrm{Cr}$ concentrations than grass hay, and clipped samples of white clover had greater $\mathrm{Cr}$ concentrations than clipped samples of grass. Jones and Buckley (1977) reported that subterranean clover contained greater $\mathrm{Cr}$ concentrations than ryegrass.

Studies in humans (Anderson and Kozlovsky, 1985) and rats (Johnson and Weaver, 1986) have indicated that the bioavailability of $\mathrm{Cr}$ naturally present in foods is low. Chromium absorption from self-selected diets of humans ranged from 0.5 to $2.0 \%$ (Anderson and Kozlovsky, 1985). Retention of ${ }^{51} \mathrm{Cr}$ from kale, wheat, and eggs intrinsically labeled with ${ }^{51} \mathrm{Cr}$ ranged from 1.1 to $1.7 \%$ of dose by d 9 after dosing (Johnson and Weaver, 1986). Bioavailability of Cr from ruminant feedstuffs and feed ingredients has received little attention. Animal feed ingredients would consist of a combination of $\mathrm{Cr}$ naturally occurring in feeds and $\mathrm{Cr}$ resulting as a contaminant from soil, metal contact, or both. Chromium in soil and from metal contamination during harvesting or processing is probably unavailable or at least of extremely low bioavailability to ruminants. Acid conditions occurring during the fermentation of silage or haylage may increase the solubility and thus the bioavailability of soil Cr. Water solubility of iron from soil was increased following fermentation of corn silage (Hansen and Spears, 2009). In alfalfa (Blincoe, 1974) and beans (Huffman and Allaway, 1973) an anionic, low-molecular-weight water-soluble $\mathrm{Cr}$ complex has been characterized. Starich and Blincoe (1983) reported that rats absorbed approximately $30 \%$ of $\mathrm{Cr}$ from ${ }^{51} \mathrm{Cr}$-labeled alfalfa. In contrast, rats fed ${ }^{51} \mathrm{Cr}-$ labeled bean leaves retained less than $0.5 \%$ of the dose after $48 \mathrm{~h}$ (Huffman and Allaway, 1973). Chromium propionate has been shown to provide bioavailable $\mathrm{Cr}$, based on its ability to enhance insulin sensitivity in cattle fed a basal diet containing $0.20 \mathrm{mg}$ of $\mathrm{Cr} / \mathrm{kg}$ of DM (Spears et al., 2012)

\section{CONCLUSIONS}

Chromium concentrations in most ruminant feedstuffs and feed ingredients are low. Mean Cr concentrations in unprocessed cereal grains are less than 0.05 $\mathrm{mg} / \mathrm{kg}$ of DM. Harvested forages contained greater $\mathrm{Cr}$ concentrations than grains, with mean $\mathrm{Cr}$ concentrations ranging from $0.155 \mathrm{mg} / \mathrm{kg}$ for grass hay to 0.522 $\mathrm{mg} / \mathrm{kg}$ for alfalfa hay or haylage. By-product feed ingredients ranged from $0.040 \mathrm{mg} / \mathrm{kg}$ for cottonseed hulls to $1.222 \mathrm{mg} / \mathrm{kg}$ for beet pulp. Grinding whole grain samples through a stainless steel Wiley mill screen greatly increased analyzed $\mathrm{Cr}$ concentrations. Much of the analyzed total $\mathrm{Cr}$ in feed ingredients appears to be due to $\mathrm{Cr}$ contamination from soil or metal contact during harvesting, processing, or both. This study indicates that the permitted concentration $(0.50 \mathrm{mg}$ of $\mathrm{Cr} / \mathrm{kg}$ of DM) of Cr Prop that can be supplemented to cattle diets is significant with regard to total dietary Cr intake.

\section{ACKNOWLEDGMENTS}

This research was supported by a grant from Kemin Industries Inc. (Des Moines, IA). The authors thank the following individuals who assisted with sample procurement: Arlene Lamptey, Joe Loughmiller, Paul Mailander, Scott Houchins, Todd Michels, Whitney Rounds, and Matt Smolen (all of Kemin Industries).

\section{REFERENCES}

Anderson, R. A., N. A. Bryden, and M. M. Polansky. 1992. Dietary chromium intake: Freely chosen diets, institutional diets, and individual foods. Biol. Trace Elem. Res. 32:117-121.

Anderson, R. A., and A. S. Kozlovsky. 1985. Chromium intake, absorption and excretion of subjects consuming self-selected diets. Am. J. Clin. Nutr. 41:1177-1183.

Bernhard, B. C., N. C. Burdick, W. Rounds, R. J. Rathmann, J. A. Carroll, D. N. Finck, M. A. Jennings, T. R. Young, and B. J. Johnson. 2012. Chromium supplementation alters the performance and health of feedlot cattle during the receiving period and enhances their metabolic response to a lipopolysaccharide challenge. J. Anim. Sci. 90:3879-3888.

Blincoe, C. 1974. Investigations of the chemical form of chromium in lucerne. J. Sci. Food Agric. 25:973-979.

Cary, E. E., W. H. Allaway, and O. E. Olson. 1977a. Control of chromium concentrations in food plants. 1. Absorption and translocation of chromium by plants. J. Agric. Food Chem. 25:300-304.

Cary, E. E., W. H. Allaway, and O. E. Olson. 1977b. Control of chromium concentrations in food plants. 2. Chemistry of chromium in soils and its availability to plants. J. Agric. Food Chem. 25:305309.

Cary, E. E., and J. Kubota. 1990. Chromium concentration in plants: Effects of soil chromium concentration and tissue contamination by soil. J. Agric. Food Chem. 38:108-114.

Edenburn, B. M., S. G. Kneeskern, B. M. Bohrer, W. Rounds, D. D. Boler, A. C. Dilger, and T. L. Felix. 2016. Effects of supplementing zinc or chromium to finishing steers fed ractopamine hydrochloride on growth performance, carcass characteristics, and meat quality. J. Anim. Sci. 94:771-779. 
Hansen, S. L., and J. W. Spears. 2009. Bioaccessibility of iron from soil is increased by silage fermentation. J. Dairy Sci. 92:2896-2905.

Hayirli, A., D. R. Bremmer, S. J. Bertics, M. T. Socha, and R. R. Grummer. 2001. Effect of chromium supplementation on production and metabolic parameters in periparturient dairy cows. J. Dairy Sci. 84:1218-1230.

Huffman, E. W. D., and W. H. Allaway. 1973. Chromium in plants: Distribution in tissues, organelles, and extracts and availability of bean leaf Cr to animals. J. Agric. Food Chem. 21:982-986.

Johnson, C. D., and C. M. Weaver. 1986. Chromium in kale, wheat, and eggs: Intrinsic labeling and bioavailability to rats. J. Agric. Food Chem. 34:436-440.

Jones, G. B., and R. A. Buckley. 1977. Levels of chromium in wheats and some other animal feedstuffs in Australia. J. Sci. Food Agric. $28: 265-268$.

Katz, S. A., and H. Salem. 1994. The Biological and Environmental Chemistry of Chromium. VCH Publishers, New York, NY.

Kneeskern, S. G., A. C. Dilger, S. C. Loerch, D. W. Shike, and T. L. Felix. 2016. Effects of chromium supplementation to feedlot steers on growth performance, insulin sensitivity, and carcass characteristics. J. Anim. Sci. 94:217-226.

Lahouti, M., and P. J. Peterson. 1979. Chromium accumulation and distribution in crop plants. J. Sci. Food Agric. 30:136-142.

Li, Y., D. F. McCrory, J. M. Powell, H. Saam, and D. Jackson-Smith. 2005. A survey of selected heavy metal concentrations in Wisconsin dairy feeds. J. Dairy Sci. 88:2911-2922.

Lima, F. R., C. X. Mendonca, J. C. Alvarez, G. Ratti, S. L. R. Lenharo, H. Kahn, and J. M. F. Garzillo. 1995. Chemical and physical evaluations of commercial dicalcium phosphates as sources of phosphorus in animal nutrition. Poult. Sci. 74:1659-1670.

Lloyd, K. E., V. Fellner, S. J. McLeod, R. S. Fry, K. Krafka, A. Lamptey, and J. W. Spears. 2010. Effects of supplementing dairy cows with chromium propionate on milk and tissue chromium concentrations. J. Dairy Sci. 93:4774-4780.

Moonsie-Shageer, S., and D. N. Mowat. 1993. Effect of level of supplemental chromium on performance, serum constituents, and immune status of stressed feeder calves. J. Anim. Sci. 71:232-238.

Mowat, D. N., X. Chang, and W. Z. Yang. 1993. Chelated chromium for stressed feeder calves. Can. J. Anim. Sci. 73:49-55.

National Academies. 2001. Dietary Reference Intakes for Vitamin A, Vitamin K, Arsenic, Boron, Chromium, Copper, Iodine, Iron,
Manganese, Molybdenum, Nickel, Silicon, Vanadium, and Zinc. National Academies Press, Washington, DC.

NRC. 2005. Mineral Tolerance of Animals. 2nd rev. ed. National Academies Press, Washington, DC.

Rafferty, B., D. E. Dawson, and P. A. Colgan. 1994. Soil and radiocaesium contamination of winter fodders. Sci. Total Environ. 153:69-76.

Rockwell, R. J., and M. S. Allen. 2016. Chromium propionate supplementation during the peripartum period interacts with starch source fed postpartum: Production responses during the immediate postpartum and carryover periods. J. Dairy Sci. 99:4453-4463.

SAS Institute. 2002. SAS User's Guide: Statistics. SAS Inst. Inc. Cary, NC

Spears, J. W., C. S. Whisnant, G. B. Huntington, K. E. Lloyd, R. S. Fry, K. Krafka, A. Lamptey, and J. Hyda. 2012. Chromium propionate enhances insulin sensitivity in growing cattle. J. Dairy Sci. 95:2037-2045

Starich, G. H., and C. Blincoe. 1983. Dietary chromium-Forms and availabilities. Sci. Total Environ. 28:443-454.

Sullivan, T. W., J. H. Douglas, and N. J. Gonzalez. 1994. Levels of various elements of concern in feed phosphates of domestic and foreign origin. Poult. Sci. 73:520-528.

Van Bibber-Krueger, C. L., J. E. Axman, J. M. Gonzalez, C. I. Vahl, and J. S. Drouillard. 2016. Effects of yeast combined with chromium propionate on growth performance and carcass quality of finishing steers. J. Anim. Sci. 94:3003-3011.

Vargas-Rodriguez, C. F., K. Yuan, E. C. Titgemeyer, L. K. Mamedova, K. E. Griswold, and B. J. Bradford. 2014. Effects of supplemental chromium propionate and rumen-protected amino acids on productivity diet digestibility, and energy balance of peak-lactation dairy cows. J. Dairy Sci. 97:3815-3821.

Welch, R. M., and E. E. Cary. 1975. Concentration of chromium, nickel, and vanadium in plant materials. J. Agric. Food Chem. 23:479-482.

Yang, W. Z., D. N. Mowat, A. Subiyatno, and R. M. Liptrap. 1996. Effects of chromium supplementation on early lactation performance of Holstein cows. Can. J. Anim. Sci. 76:221-230.

Zayed, A. M., and N. Terry. 2003. Chromium in the environment: Factors affecting biological remediation. Plant Soil 249:139-156. 